\title{
Sustainable Biogas Production Potential from Urban Wastewater in Nepal
}

\author{
S. P. Lohani, A. Chhetri, J. Adhikari, and R. Bakke
}

\begin{abstract}
In this paper, we deal with biogas production potential from urban wastewater based on published information. The usual practice of the wastewater handling in urban cities of Nepal is either direct discharge into the rivers and streams or discharge into the septic tanks. In both cases adverse environmental impacts has perceived through directly polluting rivers and streams as well as releasing methane, ammonia and hydrogen sulphide to the atmosphere. In addition to that, the lost opportunity of biogas production along with potential carbon trading can be realized which also help to make the project economically and environmentally sustainable. An estimation of methane $\left(\mathrm{CH}_{4}\right)$ production and carbon emission reduction from urban wastewater are being done allowing wastewater treatment in an anaerobic baffled reactor (ABR) and upflow anaerobic sludge blanket (UASB). In this regard, average value of some pilot plant experimental results of efficiency of chemical oxygen demand (COD) removal at ABR and UASB from various studies have been taken into consideration. The estimated biogas production potential from urban wastewater is about 22 million $\mathrm{m}^{3} /$ year equivalent to $14.5 \mathrm{MW}_{\text {th }}$ at the same time the carbon dioxide $\left(\mathrm{CO}_{2}\right)$ emission reduction potential is about 94,500 tons per year. An estimated revenue collection potential through fuel substitution is about 8 million USD per annum while additional benefits from GHG reduction and other improved condition of health, pollution and reuse of wastewater is significantly remarkable.
\end{abstract}

Index Terms-Energy recovery, wastewater, anaerobic baffled reactor, upflow anaerobic sludge blanket, chemical oxygen demand.

\section{INTRODUCTION}

Water sanitation is a core issue for public health, environment and economic growth. However, most of the wastewater produced in the world is released to the environment without treatment [1]. As a consequence, 3.3 million people die from diarrhea annually [2]. Also, millions of people are prone to cholera and typhoid especially in developing countries due to lack of sanitation and clean drinking water. The condition of water sanitation and wastewater management in Nepal is not very satisfactory, it being costly and also due to dispersed settlements in many parts of the country. The wastewater management problem in urban cities of Nepal poses a great challenge to the government of Nepal. The usual practice of wastewater disposal seems to be unacceptable as most of the wastewater is either directly discharged into the rivers or

Manuscript received April 10, 2013; revised June 26, 2013. This work was supported in part by the RenewableNepal Program, Kathmandu University, Nepal.

Sunil Prasad Lohani is with the Department of Mechanical Engineering, Kathmandu University, Nepal (email: splohani@ku.edu.np).

Rune Bakke is with Telematk University College, Prosgrunn, Norway. streams without any treatment or discharged to the septic tanks without energy recovery.

Also it has been seen that raw sewage and wastewater is being used by farmers and individuals to meet their daily water and nutrient requirements simply ignoring its severe consequence. Increasing river pollution has caused serious problems in maintaining city's beauty as well as keeping cultural and religious activities intact. Also, the healths of people exposed to polluted water are at high risks. Moreover, such practice of wastewater discharge has decreased energy and nutrients recovery potential that will ultimately release greenhouse and toxic gases to the atmosphere. Since it links sanitation, climate change and renewable energy production appropriate sanitation options are to be used.

\section{URBAN NEPAL}

Nepal is a country of 23 million people and 1, 47,000 sq. $\mathrm{km}$. of area; linear in shape, stretching $500 \mathrm{~km}$ east-west and $290 \mathrm{~km}$ north south. Geographically, the country is divided into three regions: Mountain, Hills and Tarai (plain area) and administratively, the country is divided into five development regions: eastern, central, western, mid-western and far western. In 1981, twenty three municipalities accommodated $6 \%$ of the nation's population, which in 2001 has reached to 58 municipalities by accommodating $14 \%$ of the nation's population or 3.3 million people with an average annual urban growth rate of $6.65 \%$ [3]. Today, the urban population is about 4.5 million [4].

Urban refers to metropolitan city, sub-metropolitan city, municipality and town. Urban population refers to people living in urban areas as defined by national statistical offices. The temperature of the urban areas of Nepal is directly related with the geographical condition on which it lies, which varies from hot to relatively cold climatic condition. This article basically discusses about wastewater generated from core urban areas of Nepal.

\section{WASTEWATER TREATMENT SYSTEMS}

The wastewater treatment systems based on sewerage collection and treatment facilities are broadly classified into central and decentralized treatment system. The central treatment system collects all the wastewater from the city or an area through a sewer lines which will be treated in a single plant. This system is not much cost effective and environmentally sound for all conditions since centralized treatment plants can discharge high point source loadings of pollutants into rivers or receiving waters. It also requires sophisticated technologies and skilled manpower for the 
plant operation and is often cost intensive and not feasible in areas of with low population and dispersed settlements. Moreover, such system demands huge initial investment as well as operation and maintenance cost, which countries facing structural and financial adjustment cannot afford [5], [6]. Therefore, modern or centralized wastewater treatment plants are inappropriate for communities in developing countries where often funding, resources and skilled labor are insufficient to implement, operate and maintain these plants [7]. Furthermore, from the experience of centralized wastewater treatment plant operation in Nepal it is evident that such system is not appropriate in developing countries like Nepal [8].

On the other hand, The Decentralized Wastewater Treatment System (DEWATS) might be especially an attractive choice in developing countries and allow locals to deal with their situation when there is an insufficient action taken by the central governing body [9]. The small community's settlements and even dense settlements may take this system as a best option available because it produces effluent of the same quality, or even better, as compared to a large treatment plants. The dense settlements in a large city or area may need to install several DEWATS system within their region. DEWATS is widely used not only in developing countries, but it is also widely accepted in developed countries as well [10].The decentralized technology is best suited in receiving human excreta and wastes as potential resources and solving sanitation issues as close as possible to the source of generation [11].The major advantages of the DEWATS systems are as follows [12], [13]:

- Reliable, robust and buffer shock loads

- No (or very little) energy is required

- Energy and Nutrient recovery opportunities

- Limited sludge production

- O\&M does not require highly skilled personnel

- Very low Operation and Maintenance cost

- Reduces the risks associated with system failure

- Increases wastewater reuse opportunities

The decentralized and cost effective treatment which is generally anaerobic process is then undoubtedly the best solution available for the rural and developing countries wastewater treatment problems.

Some studies have shown that anaerobic system can be best suitable as a pretreatment process, which further need to clean and lower the pollution load either in the tropical climate or mainly in cold climatic regions [14].

There are different anaerobic treatment systems available for the wastewater treatment. The most commonly used anaerobic treatment process is septic tanks (ST) or the Imhoff tank (IT). Upon smooth operation, these pretreatment process offer good removal of total suspended particles [15], [16]. Similarly, high rate anaerobic reactors like up flow anaerobic sludge blanket (UASB) and ABR (anaerobic baffle reactor) are being popular as best alternatives for sewage treatment especially in warm climates. Nevertheless, septic tank-UASB combination is also gaining attention since in this system the reactor size will be reduced which offer easy operation of digester. The septic tank-UASB system is being tested at sustainable energy systems laboratory at
Kathmandu University in collaboration with Telemark University College, Norway and may be many other parts of the world and the complete information of effluent removal efficiency and biogas generation is yet to come.

Among all of these wastewater treatment processes, depending on the local context and the requirements, appropriate treatment systems are to be selected.

\section{URBAN WASTEWATER CHARACTERISTICS}

The census population and wastewater generation in Kathmandu valley in 2011 is shown in Table I. The wastewater generated in 2011 has been used in this analysis for the estimation of methane recovery potential. Here, estimated wastewater generation is taken as 51 liters per capita per day [17] and BOD generation is $40 \mathrm{~g} /$ capita/day [18]. Moreover, wastewater characteristic is an important parameter to decide for types of treatment system. Table II shows an average influent characteristic of Guheshwori treatment plant in 2011, which is a suggesting value for the Kathmandu valley wastewater characteristics.

TABLE I: ESTIMATION OF WASTEWATER GENERATION IN KATHMANDU, 2001

\begin{tabular}{|c|c|c|c|c|}
\hline & $\begin{array}{c}\text { Population } \\
\text { in 1000 } \\
(\mathbf{2 0 1 1})\end{array}$ & $\begin{array}{c}\text { Wastewater } \\
\text { Generation, in } \\
\text { MLD }\end{array}$ & $\begin{array}{c}\text { BOD } \\
\text { Produced } \\
\text { (Kg/Yr) }\end{array}$ & $\begin{array}{c}\text { COD } \\
\text { Produced } \\
\text { (Kg/Yr) }\end{array}$ \\
\hline $\begin{array}{l}\text { Urban } \\
\text { Nepal }\end{array}$ & 4525 & 232.2 & 66065000 & 112310500 \\
\hline
\end{tabular}

TABLE II: WASTEWATER CHARACTERISTICS AT GUHESWORI PLANT IN 2011

\begin{tabular}{|c|c|c|c|}
\hline Year 2011 & TSS(mg/lit) & COD(mg/lit) & Ammonia (mg/lit) \\
\hline Month & In & In & In \\
\hline Jan-11 & 242 & 1103 & 58.5 \\
\hline Mar-11 & 345 & 1530 & 65.2 \\
\hline Apr-11 & 380 & 1255 & 40.2 \\
\hline May-11 & 287 & 1150 & 43.5 \\
\hline
\end{tabular}

Of all wastewater characteristic parameters, COD is the most general parameter to measure organic pollution as well as to estimate potential methane production. It measures how much oxygen is required to oxidize all organic and inorganic matter found in water. However, BOD is always equal to the organic fraction of the COD. It describes biological oxidation takes place with the help of bacteria. The COD, BOD ratio is taken as 1.7 for the estimation of energy generation potential [18].

In practice $\mathrm{BOD}_{5}$, which is a certain fraction of the absolute BOD is used for the analysis purpose. In this calculation 68g COD/capita/day (equivalent to $1333 \mathrm{mg} / \mathrm{lit}$ COD) is taken as an average value for the estimation of methane production [18].

\section{V.EXPERIMENTAL AND PILOT SCALE OBSERVATIONS}

Some of the laboratory and pilot plant studies of wastewater treatment systems at different parts of the world have shown that the removal efficiency of different anaerobic 
digestion processes is determined by hydraulic retention time [19] and the temperature. For tropical areas where temperature ranges from $20{ }^{\circ} \mathrm{C}$ to $35{ }^{\circ} \mathrm{C}$, the anaerobic process holds prospects for the treatment of domestic wastewater [20]. However, at low temperatures, chemical oxygen demand (COD) removal efficiency is lower and long hydraulic retention time is needed [21]. A few studies of wastewater treatment in an anaerobic baffle reactor and upflow anaerobic sludge blanket at pilot scale and a laboratory scale have shown that a range of COD removal efficiency is $47 \%$ to $93 \%$. The Table III shows that a comparative results of various studies done by different authors at different time. The above table shows that COD removal efficiency of ABR and UASB at laboratory scale experiments comes around $75 \%$ and $65 \%$ respectively, whereas the pilot plant experiments show that the removal efficiency is in the range of 50 to $90 \%$. In the estimation of biogas production potential from urban wastewater generated in Nepal, COD removal efficiency has been taken as 55\% (lower side of removal efficiency obtained in various studies of a pilot plant at different places), which is reasonable and seems to be achievable in practice in Nepal as well. The COD removal in an anaerobic digestion means an opportunity to tap biogas production during the process. Wedland, 2008 achieved 342 1t $\mathrm{CH}_{4} / \mathrm{kg}$ COD removed (or 8.4 $1 \mathrm{CH}_{4} /$ cap/day) [22], against the theoretical value of biogas production $3501 \mathrm{CH}_{4} / \mathrm{kg}$ COD removed [23], which is closely fit with theoretical values. Therefore, in this estimation the theoretical value is used for the estimation of methane production from urban wastewater in Nepal.

TABLE III: EFFICIENCY OF COD REMOVAL FOR WASTEWATER TREATMENT IN ANAEROBIC

\begin{tabular}{|l|l|l|l|l|l|}
\hline \multicolumn{1}{|c|}{ Anaerobic Baffle reactor } & Influent COD (mg/l) & Effluent COD (mg/l) & Hydraulic Retention Time & COD Removal (\%) & Reference \\
\hline Carrier ABR (Laboratory Experiment) & $\sim 350$ & $<100$ & $\begin{array}{l}48 \mathrm{~h} \\
18 \mathrm{~h}\end{array}$ & $\begin{array}{l}\sim 79 \\
\sim 69\end{array}$ & {$[24]$} \\
\hline ABR (Pilot Plant Experiment in Nepal) & $\sim 2914$ & $\sim 1421$ & 1.2 days & $\sim 47-77$ & {$[25]$} \\
\hline UASB (Lab) & $\sim 685$ & $\sim 246$ & $5 \mathrm{~h}-16 \mathrm{~h}$ & $\sim 53-76$ & {$[26]$} \\
\hline UASB (Pilot Plant) & $\sim 282$ & $\sim 124$ & $11 \mathrm{~h}$ & $\sim 54-58$ & {$[26]$} \\
\hline UASB (Field) & $\sim 1354$ & $\sim 338$ & $17 \mathrm{~h}$ & $\sim 58-93$ & {$[26]$} \\
\hline ABR (Laboratory Experiment) & $\sim 500$ & N/A & Between $6 \mathrm{~h}$ and $80 \mathrm{~h}$ & $>80$ & 70 \\
\hline ABR (Pilot Plant at Columbia) & N/A & N/A & $10 \mathrm{~h}$ & 32 & {$[27]$} \\
\hline ABR (Pilot Plant-UMBILO) & $756 \pm 36$ & $170 \pm 54$ & $32 \mathrm{~h}$ & 66 (average) & {$[28]$} \\
\hline
\end{tabular}

TABLE IV: ESTIMATED ENERGY GENERATION FROM URBAN WASTEWATER IN NEPAL

\begin{tabular}{|c|c|c|c|c|c|c|c|}
\hline $\begin{array}{l}\text { Urban } \\
\text { Nepal }\end{array}$ & $\begin{array}{l}\text { Population in } \\
\text { ' } 000(2011)\end{array}$ & $\begin{array}{c}\text { Estimated COD } \\
\text { Production } \\
(\mathrm{Kg} / \mathrm{Yr})\end{array}$ & $\begin{array}{c}\text { Estimated COD } \\
\text { Removal } \\
(\mathrm{Kg} / \mathrm{Yr})\end{array}$ & $\begin{array}{c}\text { Estimated Methane } \\
\text { Production rate } \\
\left(\mathrm{Nm}^{3} / \mathrm{Yr}\right)\end{array}$ & $\begin{array}{c}\text { Estimated Biogas } \\
\text { Production } \\
\left(\mathrm{Nm}^{3} / \mathrm{yr}\right)\end{array}$ & $\begin{array}{c}\text { Estimated } \\
\text { Energy Value } \\
\left(\mathrm{MW}_{\mathrm{th}}\right)\end{array}$ & $\begin{array}{l}\text { Estimated energy } \\
\text { value in terms of } \\
\text { liters of kerosene }\end{array}$ \\
\hline & 4525 & 112310500 & 61770775 & 21619771 & 33261187 & 21 & 16630594 \\
\hline
\end{tabular}

\section{Estimated BIOGAS PRoduction}

Based on the pilot scale experimental observations (table 3), 55\% COD removal efficiency and $3501 \mathrm{CH} 4 / \mathrm{kg} \mathrm{COD}$ removal [23] has taken as a reference value. Estimated energy generation from urban areas wastewater is shown in Table IV. The Methane content in the biogas is taken as $65 \%$ and energy value of biogas is $20 \mathrm{MJ}$ per $\mathrm{m}^{3}$. Moreover, each $\mathrm{m}^{3}$ of biogas is equivalent to half a liter of kerosene. The estimated COD produced in the Urban Areas of Nepal is about 66065 ton/yr. out of which 3633.6 ton COD (55\% removal efficiency) can be removed by using appropriate anaerobic digestion system. The estimated methane production is 14.8 million $\mathrm{m}^{3} / \mathrm{yr}$, which is equivalent to 456 million MJ or $14.5 \mathrm{MWth}$ or 11.4 million liter of Kerosene per year.

\section{ECONOMIC AND ENVIRONMENTAL EVALUATION}

At present most of the wastewater generated in Nepalese municipalities are not being managed adequately thereby creating a serious health and environmental hazard, however, there are not much study about this.

Wastewater handling contributes in methane emission since methane is generated under anaerobic condition and the handling of wastewater is generally an important factor to decide on the quantity of methane emission from this sector [18]. In rural Nepal, domestic and commercial wastewater is handled by discharging it into the open pits/latrines, aerobic shallow ponds, streams and rivers with few exceptions of discharging in septic tanks [29]. However, in urban cities the domestic and commercial wastewater is discharged into septic tanks, sewerage system, river and streams, and shallow ponds and deep lagoons [30]. Similarly, industrial wastewater handling practice resembles domestic and commercial ones [29]. Due to accumulation of sludge in septic tanks, deep lagoons, and ponds, anaerobic conditions develop and hence these facilities produce biogas containing sizeable proportion of methane (CH4). Nevertheless, the indirect Nitrous oxide (N2O) emission due to denitrification of ammonium-nitrogen (NH4-N) presents in human sewage is also accounted [18]. Moreover, discharge of wastewater at open pits, shallow ponds, rivers and streams causes contamination on surface water, serious threats on aquatic life, degradation of aesthetic beauty and health concern to those exposed [31]. The energy recovery estimation presented in table 4 shows that Methane production from 
urban domestic and commercial wastewater is about 15134 tons/yr (taking biomethane density of $0.7 \mathrm{~kg} / \mathrm{Nm}^{3}$ ), which is equivalent to 317814 tons of Carbon dioxide per year (taking global warming potential of Methane for a time horizon of 100 years is $1 \mathrm{~kg} \mathrm{CH} 4$ equivalent to $21 \mathrm{~kg} \mathrm{CO} 2$ ). Therefore, if there are an implementation of anaerobic digestion wastewater treatment systems, energy recovery in the form of biogas from urban wastewater is then equivalent to 16.6 million liters of kerosene and at the same time current Methane emission to the atmosphere from the wastewater due to unwanted anaerobic process can be reduced if not completely eliminated. The initial national communication of Nepal estimates shows that about $6 \mathrm{Gg}$ (6000 tons) per year methane, which is equivalent to 126,000 tons per year carbon dioxide is emitted to the atmosphere in 2010/11 due to unwanted anaerobic activities during wastewater handling [29]. Nevertheless, If all urban wastewater passes through the anaerobic treatment process only about $10 \%$ of Methane which is equivalent to 1513 tons/yr will be emitted back to the atmosphere as fugitive emission as leakage from anaerobic reactor and incomplete digestion [18]. This estimates shows that if we implement anaerobic digestion of wastewater, about 4500 tons per year methane emission, which is equivalent to 94,500 tons per year carbon dioxide equivalent (current level of methane emission of 6000 tons/year will be reduced but 1513 tons/year methane emission goes back to the atmosphere as fugitive emission, therefore net balance of about 4500 ton/year methane emission will be reduced) can be reduced from the current level of emission. In addition to that about 13,600 tons per year methane (subtracted fugitive emission 1513 ton/year from total methane production 15134 ton/year) can be available for energy use. This will have a substantial contribution in climate change mitigation from wastewater sector in a country like Nepal.

Biogas can replace fossil fuels, thus reducing the emission of GHGs and other harmful emissions, by tapping and using it as a source of energy. Municipalities and government can use this anaerobic treatment to solve problems regarding waste water management. The table 5 shows that the revenue generation by replacing kerosene with biogas as a fuel. About 17.3 million USD per year revenue can be generated from fuel substitution alone. If the additional benefits from GHG reduction such as potential carbon market, improved health risk condition, potential reuse of treated wastewater for irrigation, sludge as fertilizer is considered, the proposed system that is biogas production from anaerobic treatment of domestic and commercial wastewater can prove to be a sustainable one.

TABLE V: REVENUE GENERATION FROM USE OF BIOGAS INSTEAD OF KEROSENE

\begin{tabular}{|c|c|c|c|}
\hline \multirow{4}{*}{ Fuel-stove } & $\begin{array}{c}\text { Biogas } \\
\text { Production } \\
\text { capacity in } \\
\mathrm{Nm}^{3} / \mathrm{yr} .\end{array}$ & $\begin{array}{c}\text { In terms of } \\
\text { kerosene(lit) }(1 \mathrm{~m} 3 \\
\text { Biogas=0.5 } 1 \text { fuel oil) }\end{array}$ & $\begin{array}{c}\text { Revenue(\$) } \\
\text { (Rate 88 } \\
\text { NRs=1\$) }\end{array}$ \\
\hline Biogas & 33261187 & 16630594 & 17295818 \\
\hline
\end{tabular}

(1 liter kerosene cost about 1.04 USD in Sep. 2012 Price Nepal)

\section{CONCLUSION}

Population density in Nepal is putting immense pressure on municipal services, particularly to manage the ever increasing amounts of waste water. At present most of the wastes generated in municipalities are not being adequately managed thereby creating serious health and environmental hazards. It is crucial to take necessary step of sanitation measures, which should help reduce pollutant disposal in the rivers. A simple and practical system called anaerobic baffle reactor (ABR), up flow anaerobic sludge blanket (UASB) or Septic tank-UASB combination can prove to be a sustainable solution for wastewater treatment in developing countries like Nepal. In addition to the wastewater treatment, the estimated energy recovery from such treatment system is nearly 456 million $\mathrm{MJ} / \mathrm{yr}\left(14.5 \mathrm{MW}_{\text {th }}\right)$, which is equivalent to 11.4 million liter of kerosene. It shows that the proposed wastewater treatment can not only reduce water pollutants in the rivers and streams but also save huge amount of fossil fuel from being used and the water can be used again for irrigation purpose. Moreover, reduce Methane emission of about 9300 ton/yr from wastewater as a result of Methane recovery in the treatment system can be possible that will create positive impact in fuel dependency and climate change.

\section{REFERENCES}

[1] P. Lens, G. Zeeman, and G. Lettinga, "Decentralized sanitation and Reuse: Concepts, systems and implementation," WIA publishing, UK. 2001 .

[2] World health organization, WHO, 1996.

[3] Central Bureau of Statistics, CBS, Nepal, 2001.

[4] Central Bureau of Statistics, CBS, Nepal, 2011.

[5] I. M. KengneNoumsi, A. Akoa, R. AtanganEteme, J. Nya, A. Ngniado, T. Fonkou, and F. Brissaud, "Mosquito development and biological control in a microphyte-based wastewater treatment plant," Water SciTechnology, vol. 51, no. 12, pp. 201-204, 2005a.

[6] I. M. KengneNoumsi, F. Brissaud, A. Akoa, R. AtanganEteme, J. Nya, A. Ndikefor, and T. Fonkou, "Microphyte and macrophyte based lagooning in tropical regions," Water SciTechnology, vol. 51, no. 12, pp. 267-274, 2005b.

[7] G. Zeeman and G. Lettinga, "The role of anaerobic digestion of domestic sewage in closing the water and nutrient cycle at community level," Water Sci. Technol., vol. 39, no. 5, pp. 187-194, 1999.

[8] A. Bohara L. Shakya, and S. Sha, "Analysis of existing wastewater treatment systems and energy recovery potential from Kathmandu Valley," Undergraduate thesis, Department of Environment Engineering, Kathmandu University, 2011.

[9] W. Green and G. Ho, "Small scale sanitation technologies," Water SciTechnology, vol. 51, no. 10, pp. 29-38, 2005.

[10] J. Kegebein, E. Hoffmann, and H. H. Hahn, "Performance of very small wastewater treatment plants with pronounced load variations," Water SciTechnol, vol. 55, no. 7, pp. 31-38, 2007.

[11] EAWAG-Decentralized Wastewater Treatment. (2008). [Online]. Available:http://www.eawag.ch//organisation/abteilungen/sandec/sch werpunkte/ewm/dewat/index EN.

[12] L. Sasse, "DEWATS - Decentralised wastewater treatment in Developing Countries," Bremen Overseas Research and Development Association (BORDA), Bremen, Germany, 1998.

[13] F. Brissaud, "Low technology systems for wastewater treatment: perspectives," Water SciTechnol, vol. 55, no. 7, pp. 1-9, 2007.

[14] J. A. A’lvarez, C. A. Zapico, M. G' omez, J. Presas, and M. Soto, "Anaerobic hydrolysis of a municipal wastewater in a pilot-scale digester," Water Sci. Technol, vol. 47, no. 12, pp. 223-230, 2003.

[15] S. Neralla, R. W. Weaver, B. J. Lesikar, and R. A. Persyn, 2000. Improvement of domestic wastewater quality by subsurface flow constructed wetlands. Bioresour. Technol. 75, 19-25.

[16] J. Vymazal, "The use of sub-surface constructed wetlands for wastewater treatment in the Czech Republic: 10 years experience," Ecol. Eng, vol. 18, pp. 633-646, 2002. 
[17] Kathmandu, "Valley water distribution, sewerage, and urban development project," Technical Assistance Consultant's Report, pp. 1-106, ADB, 2006.

[18] IPCC, "IPCC 2006 guidelines for national greenhouse gas inventories," 2006.

[19] H. Fang, L. Hu, Q. Mahmood, C. Qiu, C. Fang, and D. Shen, "Anaerobic domestic wastewater treatment with bamboo carrier anaerobic baffled reactor," International Biodeterioration \& Biodegradation, vol. 62, pp. 232-238, 2008.

[20] A. C. Haandel and G. Lettinga, Anaerobic sewage treatment, Chichester: John Wiley \& Sons, 1994.

[21] G. Zeeman and G. Lettinga, "The role of anaerobic digestion of domestic sewage in closing the water and nutrient cycle at community level," Water Sci. Technol., vol. 39, no. 5, pp. 187-194, 1999.

[22] C. Wendland, "Anaerobic digestion of blackwater and kitchen refuse," PhD thesis, TUTH, Technische Universitat Hamburg -Harburg, 2008.

[23] R. Zahlten. (June 12, 2012). Technology for Economic Development, [Online]. Available: http://www.ted-biogas.org/index.php?id=28.

[24] F. Huajun, H. Lifang, M. Qaisar, Q. Caidi, F. Chengran, and S. Dongsheng, "Anaerobic domestic wastewater treatment with bamboo carrier anaerobic baffled reactor," International Biodeterioration \& Biodegradation, vol. 62, pp. 232-238, 2008.

[25] S. Singh, R. Haberl, O. Moog, R. R. Shrestha, P. Shrestha, and R. Shrestha, "Performance of an anaerobic baffled reactor and hybrid constructed wetland treating high-strength wastewater in Nepal-A model for DEWATS," Ecological Engineering, vol. 35, pp. 654-660, 2009.

[26] J. A. A' lvarez and M. Ru'iz I. Soto, "Anaerobic digesters as a pretreatment for constructed wetlands," Ecological Engineering, vol. 33, pp. 54-67, 2008.
[27] A. A. M. Langenhoff and D. C. Stuckey, "Treatment of dilute wastewater using an anaerobic baffled reactor, Effect of low temperature," Water Research, vol. 34, no. 15, pp. 3867-3875, 2000.

[28] K. M. Foxon, "Analysis of a pilot-scale anaerobic baffled reactor treating domestic wastewater," $\mathrm{PhD}$ Thesis, School of Chemical Engineering University of KwaZulu-Natal, Durban, 2009.

[29] MOPE, Nepal Initial National Communication to the Conference of the Parties of the United Nations Framework Convention on Climate Change, Ministry of Population and Environment, Kathmandu, Nepal, 2004

[30] ADB, "Kathmandu valley water distribution, sewerage, and urban development project feasibility study," Asian Development Bank, pp. 37, 2006.

[31] WHO, Guidelines for the safe use of wastewater, excreta and greater, vol. 3, pp. 47-52, World Health Organization Press, Geneva, Switzerland, 2006.

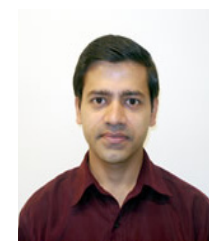

Sunil Prasad Lohani is currently working as assistant professor at Department of Mechanical Engineering, Kathmandu University, Dhulikhel, Nepal. He is leading an Anaerobic Treatment of Wastewater Project within the Department.

Rune Bakke is a professor at Institute of Energy, Environment and Process Technology, Telemark University College, Norway. 